\title{
Jurnal Ilmu Kehutanan
}

\author{
Journal of Forest Science
}

https://jurnal.ugm.ac.id/jikfkt

\section{Studi Mutu Kayu Jati di Hutan Rakyat Gunungkidul. VI. Kadar Zat Anorganik dan Keasaman}

\author{
Study of Teakwood Quality from Community Forests in Gunungkidul. \\ VI. Inorganic Material Contents and Acidity
}

Ganis Lukmandaru* \& Rudy Nur Hidayah

Departemen Teknologi Hasil Hutan, Fakultas Kehutanan, Universitas Gadjah Mada, Jl. Agro No.1, Bulaksumur, Sleman 55281

*E-mail : ganisarema@lycos.com

\section{HASIL PENELITIAN}

Riwayat naskah:

Naskah masuk (received): 8 Juni 2016

Diterima (accepted): 4 Oktober 2016

\section{KEYWORDS}

Tectona grandis

pH value

ash content

silica

inorganic naterials

\begin{abstract}
Inorganic materials and acidity in the wood has been proved to affect the wood properties. The previous paper in this series reported on the physical and chemical properties of teak wood from community forests. Therefore, this study aimed to explore the content of inorganic materials and acidity of teak wood grown in the 3 sites (Panggang, Playen, Nglipar) with different ecological attributes from community forests in Gunungkidul. The evaluated parameters were $\mathrm{pH}$ values, the contents of ash (ASTM D-1102), silica and silicates (SNI 14-1031-1989), and inorganic matters (Ca, Mg, K, Na, $\mathrm{Fe}, \mathrm{Mn}$, and $\mathrm{Cu}$ ) by means of Atomic Absorption Spectrophotometer. The ranges of ash and silica-silicates content were $0.38-2.62 \%$, and $0.01-1.17 \%$, respectively. The ranges of inorganic element content for $\mathrm{Ca}, \mathrm{K}, \mathrm{Mg}, \mathrm{Na}$, and Fe were 408-2919 ppm; 69-23705 ppm; 947-1653 ppm; 4-31 ppm; and o326 ppm, respectively whereas $\mathrm{Mn}$ and $\mathrm{Cu}$ were not detected in any samples. Further, the obtained $p H$ values range was 5.23-6.98. On the basis of analysis of variance, the contents of ash, silica-silicates, and Na were affected significantly by site and radial direction (sapwood, outer heartwood, and inner heartwood) factors. The woods from Playen (middle zone/Ledok Wonosari) had significantly high in ash and silica-silicate contents. By Kruskal-Wallis test, radial direction factor affected significantly the levels of $\mathrm{Ca}, \mathrm{K}$, and $\mathrm{Mg}$. As defined by Pearson's correlation analysis, it was found a strong correlation between the ash and silica-silicates contents ( $r=0.77-0.88$ ), as well as between the ash-Ca content $(r=-0.51)$ and the ash-Mg content $(r=0.59)$ in the heartwood part. In the inorganic element levels, the strongest correlation was measured between $\mathrm{Ca}-\mathrm{Mg}$ content (r=-0.46). Special attention should be given to the comparatively high amounts of the silica-silicates content in the observed samples as it would dull cutting tools considerably.
\end{abstract}


KATA KUNCI

Tectona grandis

nilai $\mathrm{pH}$

kadar abu

silika

zat anorganik

\section{INTISARI}

Zat anorganik dan keasaman telah terbukti dalam mempengaruhi sifat-sifat kayu. Paper-paper sebelumnya dalam seri ini telah membahas sifat fisik dan kimia kayu jati dari hutan rakyat. Untuk itu, penelitian ini bertujuan untuk mengeksplorasi kadar zat anorganik dan keasaman kayu jati dari hutan rakyat Gunungkidul di 3 tempat tumbuh dengan zona ekologis berbeda (Panggang, Playen, Nglipar). Parameter yang diteliti adalah nilai pH, kadar abu (ASTM D-1102), kadar silika dan silikat (SNI 14-1031-1989), dan kadar unsur zat anorganik (Ca, Mg, K, Na, Fe, Mn, dan $\mathrm{Cu})$ melalui Atomic Absorption Spectrophotometer. Kisaran kadar abu serta kadar silika dan silikat secara berurutan adalah 0,38-2,62\%, dan o,o1-1,17\%. Kisaran nilai kadar zat anorganik Ca, K, Mg, Na, dan Fe adalah 408-2919 ppm; 69-23705 ppm; 947-1653 ppm; 4-31 ppm; dan o-326 ppm, secara berturutan sedangkan Mn dan Cu tidak terdeteksi di semua sampel. Selanjutnya, kisaran nilai $\mathrm{pH}$ yang diperoleh sebesar 5,23 - 6,98. Berdasarkan analisis variansi, kadar abu, silika-silikat, dan Na dipengaruhi oleh faktor tempat tumbuh dan arah radial pohon (gubal, teras luar, dan teras dalam). Kayu dari Playen (zona tengah/Ledok Wonosari) menunjukkan nilai yang cukup tinggi untuk kadar abu dan silika-silikat. Faktor arah radial pohon berpengaruh nyata pada unsur $\mathrm{Ca}$, $\mathrm{K}$, dan $\mathrm{Mg}$ melalui uji Kruskal-Wallis. Dari analisis korelasi Pearson, didapatkan hubungan kuat antara kadar abu dengan kadar silika-silkat $\left(\mathrm{r}=0,77^{-0}, 88\right)$ serta kadar abu-Ca $(\mathrm{r}=-0,51)$ dan kadar abu-Mg $(\mathrm{r}=0,59)$ di bagian teras. Dalam tingkat unsur, hubungan terkuat diamati pada kadar Ca-Mg $(\mathrm{r}=$ -o,46). Perhatian khusus perlu diberikan pada kadar silika-silkat yang relatif tinggi di sampel yang diamati karena pengaruhnya terhadap penumpulan peralatan gergaji.

(c) Jurnal Ilmu Kehutanan Allright reserved

\section{Pendahuluan}

Kayu jati merupakan salah satu jenis kayu komersial yang diminati dan paling banyak digunakan oleh masyarakat Indonesia karena corak kayu yang indah, berkesan mewah, mudah pengerjaannya serta keawetan alami yang relatif tinggi. Selain hutan tanaman di Jawa, jati juga merupakan tanaman yang mendominasi hutan rakyat di D.I. Yogyakarta seperti halnya di Kabupaten Gunungkidul. Selain untuk konsumsi pengrajin kayu lokal, hasil penebangan dari hutan rakyat Gunungkidul telah dipasarkan ke sentra mebel dan kerajinan seperti di Jepara, Klaten, Pekalongan, dan daerah di Jawa lainnya.

Mutu kayu jati juga tidak terlepas dari komponen anorganik atau mineral di dalam selnya. Salah satunya adalah komponen silika yang bisa berpengaruh terhadap penumpulan alat pemotong (Shmulsky \& Jones 2011). Selain komponen silika, komponen utama anorganik lainnya berpengaruh pada sulitnya kayu jati untuk direkat (Kanazawa et al. 1978). Pada spesies lainnya, zat-zat tersebut berpengaruh pada penghitaman kayu (Takahashi 1996; Minato \& Morita 2005) maupun pertumbuhan pohonnya (Kuhn et al. 1997). Sifat kimia lainnya seperti keasaman kayu bisa berpengaruh pada perubahan warna kayunya, kemudahan direkat pada papan serat atau partikel, pengikatan zat-zat pelindung kayu, perlakuan permukaan serta perkaratan logam bila kontak dengan kayu (Hachmi \& Moslemi 1990; Fengel \& Wegener 1989; Xing et al. 2004; Mayer \& Koch 2007).

Disebabkan pengaruh pentingnya terhadap sifat kayu maupun pengolahannya serta terbatasnya data yang ada, maka perlu dilakukan penelitian dengan 
sampel berasal dari hutan rakyat. Untuk sifat kimia kayu, penelitian sebelumnya dengan objek kayu dari hutan rakyat di Yogyakarta lebih difokuskan ke komposisi ekstraktif yang dihubungkan dengan sifat ketahanan alami terhadap rayap (Lukmandaru 2011, 2013; Lukmandaru \& Sayudha 2012). Penelitian pendahuluan untuk kayu jati dari hutan rakyat Gunungkidul menunjukkan arah radial dan tempat tumbuh berpengaruh nyata terhadap variasi sifat fisik (Marsoem et al. 2014, 2015) maupun sifat kimia secara umum (Lukmandaru et al. 2016). Untuk itu, dalam rangka melengkapi data yang ada dari hutan tanaman Perhutani (Lukmandaru 2010, 2011, 2012), maka penelitian ini bertujuan untuk mengekplorasi kadar zat anorganik dan keasaman kayu jati dari hutan rakyat. Selain itu, korelasi antara parameter zat anorganik dan keasaman kayunya juga dibahas dalam paper ini.

\section{Bahan \& Metode}

\section{Penyiapan sampel}

Bahan baku kayu jati diperoleh dari hutan rakyat di tempat tumbuh yang berbeda di Kabupaten Gunungkidul, yaitu Desa Kedungkeris, Kecamatan Nglipar (zona selatan, Gunung Seribu), Girisekar, Panggang (zona utara, Batur Agung), dan Dengok, Playen (zona tengah, Ledok Wonosari). Deskripsi tempat tumbuh disajikan di Tabel 1 sedangkan deskripsi pohon dijelaskan pada publikasi sebelumnya (Marsoem et al. 2014; Lukmandaru et al. 2016). Dari masing-masing tempat tumbuh di zona ekologis yang berbeda tersebut, diambil tiga buah pohon sebagai ulangan pada diameter kisaran 28-37 cm. Jumlah lingkaran tahun dalam kisaran 10-21 dan persen teras $33-74 \%$. Cara penentuan sampel (pohon) adalah secara acak, yaitu dipilih pohon yang mempunyai fisik yang bagus dan tidak cacat. Dari setiap pohon, sampel uji kayu diambil dari bagian pangkal (sekitar $20 \mathrm{~cm}$ dari tanah) dalam bentuk disk. Dalam setiap penampang melintang (arah radial) disk, dibagi menjadi tiga bagian, yaitu gubal $( \pm 0,5 \mathrm{~cm}$ dari kulit $\mathrm{kayu}$ ), teras luar ( $0,5 \mathrm{~cm}$ dari perbatasan gubal-teras), dan teras dalam $( \pm 1 \mathrm{~cm}$ dari empulur). Selanjutnya, tiap bagian tersebut dibor dan dibuat serbuk dengan ukuran 40-6o mesh.

\section{Penentuan kadar abu, kadar silika dan silikat, serta kadar unsur-unsur anorganik}

Data kadar abu telah diukur dalam penelitian sebelumnya (Lukmandaru et al. 2016). Serbuk ditimbang setara $2 \mathrm{~g}$ kering tanur untuk pengabuan mengacu ASTM D-1102 (2002) yaitu pada suhu sekitar $600^{\circ} \mathrm{C}$. Kadar abu dihitung berdasarkan persentase berat serbuk awal setara kering tanur. Kadar silika dan silikat (KSS) dihitung dengan pendekatan residu zat anorganik dari penentuan kadar abu yang tak larut asam klorida $(\mathrm{HCl})$ 6M mengacu SNI 14-1031-1989 (1989). Untuk penentuan unsur-unsur kadar abu, filtrat pengukuran silika dan silikat dicuplik sebagian kemudian diukur komponen kalsium (Ca), magnesium $(\mathrm{Mg})$, potassium $(\mathrm{K})$, besi $(\mathrm{Fe})$, mangaan $(\mathrm{Mn})$, tembaga $(\mathrm{Cu})$, dan sodium $(\mathrm{Na})$ melalui alat Atomic Absorption Spectrophotometer (AAS) Analitik Jena

Tabel 1. Deskripsi kondisi sampel dan tempat tumbuh Table 1. Description of the sampling and sites

\begin{tabular}{lccc}
\hline \multicolumn{1}{c}{ Asal } & Nglipar & Panggang & Playen \\
\hline Ketinggian tempat (m dpl) & 115 & 270 & 150 \\
Batuan induk & Vulkanik & Kapur & Kapur \\
Tipe tanah & Mediteran, lempung & Latosol, berbatu & Grumusol, lempung berat \\
Kalsium total (\%) & $\mathbf{0 , 8 5}$ & 6,68 & $\mathbf{2 , 2 2}$ \\
Potassium total (\%) & $\mathbf{0 , 0 4}$ & $\mathbf{0 , 0 9}$ & $\mathbf{0 , 0 4}$ \\
Magnesium total (\%) & $\mathbf{0 , 5 1}$ & $\mathbf{0 , 4 6}$ & $\mathbf{0 , 5 3}$ \\
Nilai pH & 6,69 & 7,55 & 6,88 \\
\hline
\end{tabular}

Keterangan : pengukuran kalsium, potassium, dan magnesium total dilakukan dengan metode ekstraksi $\mathrm{HNO}_{3}$ dan $\mathrm{HClO}_{4}$ di Lab. Fisiologi dan Tanah Hutan, Fak. Kehutanan UGM.

Remarks : measurements of calcium, potassium and magnesium were conducted by extraction $\mathrm{HNO}_{3}$ dan $\mathrm{HClO}_{4}$ method in the Laboratory of Physiology and Forest Soil, Faculty of Foresty UGM 
300 series (Laboratorium Penelitian dan Pengujian Terpadu, UGM). Kalibrasi dilakukan dengan kontrol tanpa abu dan hasil dinyatakan dalam ppm.

\section{Penentuan nilai pH}

Sebanyak $1 \mathrm{~g}$ serbuk kayu setara kering tanur direndam dalam aquades $20 \mathrm{ml}$ selama $48 \mathrm{jam}$. Setelah disaring, filtrat diukur nilai pH-nya dengan OAKTON pH tester.

\section{Analisis data}

Data dari penelitian ini akan dianalisis secara statistik dan menggunakan rancangan percobaan acak lengkap (Completely Randomized Design) yang disusun dengan percobaan secara faktorial untuk 2 faktor, yaitu tempat tumbuh (Panggang, Playen, Nglipar) dan arah radial (gubal, teras luar, teras dalam). Setiap parameter diuji normalitas datanya menggunakan uji Kolmogorov-Smirnov. Analisis varians (ANOVA) dwi-arah univariat dihitung untuk mengetahui faktor yang berpengaruh pada tingkat 95\% untuk data berdistribusi normal dan uji perbandingan berganda Duncan sebagai uji lanjut. Metode non-parametrik uji Kruskal-Wallis digunakan untuk menghitung pengaruh faktor tunggal nyata pada tingkat $95 \%$ untuk data berdistribusi tidak normal sedangkan uji Mann-Whitney secara bertahap digunakan sebagai uji lanjut. Korelasi Pearson digunakan untuk menilai keeratan hubungan antara parameter yang diteliti. Seluruh perhitungan statistik menggunakan program Excel (MS Word 2007) dan SPSS versi 16.0

\section{Hasil \& Pembahasan}

Dalam eksperimen ini digunakan metode pengabuan kering sedangkan kadar silika-silikat dan komponen anorganik lainnya ditentukan dengan pelarutan abu yang tersisa dalam asam kuat. Pengukuran keasaman kayu melalui nilai pH serbuk kayu rendaman dingin. Kisaran keseluruhan data disajikan dalam Tabel 2 sedangkan hasil analisis variansi pada Tabel 3.

\section{Kadar abu serta kadar silika dan silikat (KSS)}

Zat anorganik dalam kayu mengindikasikan keberadaan unsur logam dan non-logam yang berasal dari proses fisiologis pohon. Kadar abu pada kayu teras antara 0,74\%-1,98\% dan gubal antara 0,38\%-2,62\%. Dari hasil ANOVA tidak didapatkan interaksi yang nyata terhadap dua parameter tersebut tetapi kedua faktor tunggal berpengaruh nyata

Tabel 2. Kadar abu, kadar silika dan silikat, kadar unsur-unsur anorganik, dan nilai pH kayu jati dari hutan rakyat Kabupaten Gunungkidul.

Table 2. The contents of ash, silica and silicates, inorganic elements, and $\mathrm{pH}$ values of teakwood of community forests from Gunungkidul Regency.

\begin{tabular}{|c|c|c|c|c|c|c|c|c|c|}
\hline \multirow{2}{*}{ Parameter } & \multicolumn{3}{|c|}{ Nglipar } & \multicolumn{3}{|c|}{ Panggang } & \multicolumn{3}{|c|}{ Playen } \\
\hline & Min. & Maks. & Rerata \pm sd & Min. & Maks. & Rerata \pm sd & Min. & Maks. & Rerata \pm sd \\
\hline Kadar abu (\%) & 0,74 & 1,31 & $1,07 \pm 0,20$ & 0,38 & 1,18 & $0,81 \pm 0,24$ & 1,16 & 2,14 & $1,52 \pm 0,34$ \\
\hline $\begin{array}{l}\text { Kadar silika dan } \\
\text { silikat (\%) }\end{array}$ & 0,26 & 0,70 & $0,45 \pm 0,17$ & 0,01 & 0,60 & $0,25 \pm 0,17$ & 0,31 & 1,17 & $0,54 \pm 0,27$ \\
\hline Kalsium (ppm) & 506 & 2919 & $1308 \pm 923$ & 555 & 1183 & $813 \pm 221$ & 408 & 1416 & $75^{2} \pm 303$ \\
\hline Potassium (ppm) & 174 & 23705 & $3500 \pm 1366$ & 69 & 4459 & $1679 \pm 1220$ & 264 & 4417 & $1666 \pm 1562$ \\
\hline Magnesium (ppm) & 1195 & 1653 & $1388 \pm 237$ & 947 & 1561 & $1454 \pm 113$ & 960 & 1581 & $1325 \pm 193$ \\
\hline Besi (ppm) & $\mathrm{tt}$ & $\mathrm{tt}$ & - & $\mathrm{tt}$ & tt & - & $\mathrm{tt}$ & 326 & - \\
\hline Sodium (ppm) & 9,33 & 25,61 & $13,92 \pm 7,54$ & 4,32 & 26,87 & $21,71 \pm 4,49$ & 5,57 & 30,62 & $10,89 \pm 6,65$ \\
\hline Mangaan (ppm) & $\mathrm{tt}$ & $\mathrm{tt}$ & - & $\mathrm{tt}$ & tt & - & $\mathrm{tt}$ & tt & - \\
\hline Tembaga (ppm) & $\mathrm{tt}$ & $\mathrm{tt}$ & - & $\mathrm{tt}$ & tt & - & $\mathrm{tt}$ & $\mathrm{tt}$ & - \\
\hline Nilai pH & 5,23 & 6,54 & $5,83 \pm 0,56$ & 5,50 & 6,98 & $5,89 \pm 0,41$ & 5,31 & 6,54 & $6,03 \pm 0,35$ \\
\hline
\end{tabular}

Keterangan $:$ min. $=$ minimum, maks. = maksimum, $\mathrm{sd}=$ standar deviasi, $\mathrm{tt}=$ tidak terdeteksi

Remarks $:$ min. $=$ minimum, maks. $=$ maximum, $\mathrm{sd}=$ standar deviation, $\mathrm{tt}=$ not detected 
Tabel 3. Analisis variansi dari parameter zat anorganik dan nilai pH dari kayu jati hutan rakyat Kabupaten Gunungkidul. Table 3. Analysis of variance of inorganic materials and $\mathrm{pH}$ values of teakwood of community forests from Gunungkidul Regency.

\begin{tabular}{|c|c|c|c|c|c|c|c|c|c|}
\hline \multirow{2}{*}{$\begin{array}{c}\text { Sumber } \\
\text { variasi }\end{array}$} & \multirow{2}{*}{$\mathrm{db}$} & \multicolumn{2}{|c|}{ Kadar abu } & \multicolumn{2}{|c|}{ Kadar silika dan silkat } & \multicolumn{2}{|c|}{ Kadar sodium } & \multicolumn{2}{|c|}{ Nilai pH } \\
\hline & & KT & $\mathrm{F}$ & $\mathrm{KT}$ & $\mathrm{F}$ & KT & $\mathrm{F}$ & KT & $\mathrm{F}$ \\
\hline $\mathrm{R}$ & 2 & 0,259 & $3,621^{*}$ & 0,167 & $4,204^{*}$ & 286,326 & $8,315^{* *}$ & o,097 & 0,435 \\
\hline $\mathrm{T}$ & 2 & 1,173 & $16,420^{* *}$ & 0,195 & $4,902^{*}$ & 33,237 & 0,965 & 0,185 & 0,827 \\
\hline TxR & 4 & o,oo1 & 0,021 & o,o10 & 0,246 & 69,748 & 2,025 & 0,150 & 0,671 \\
\hline Galat & 18 & 0,071 & & 0,040 & & 34,436 & & 0,223 & \\
\hline
\end{tabular}

Keterangan : $\mathrm{T}$ : tempat tumbuh; $\mathrm{R}$ : arah radial; $\mathrm{db}$ : derajat bebas; $\mathrm{KT}:$ rerata kuadrat tengah

** = beda sangat nyata pada taraf uji $1 \% \quad *$ * beda nyata pada taraf uji $5 \%$

Remarks : T : sites; $\mathrm{R}$ : radial direction; $\mathrm{db}$ : degrees of freedom; $\mathrm{KT}:$ mean squares

${ }^{* *}=$ highly significant at $\alpha=1 \%,{ }^{*}=$ significant at $\alpha=5 \%$,

dimana posisi gubal dan tempat tumbuh Playen menunjukkan nilai tertinggi (Lukmandaru et al. 2016).

Kisaran nilai KSS adalah o,16\%-0,76\% di teras dan 0,01\%-1,17\% di gubal dengan kecenderungan hasil ANOVA serupa dengan kadar abu. Untuk arah radial, uji Duncan nilai rerata tertinggi (o,57\%) secara nyata didapatkan pada bagian teras luar untuk KSS berdasarkan (Gambar 1).

Perbedaan tempat tumbuh berpengaruh nyata dimana sampel Playen menunjukkan nilai kadar abu $(1,53 \%)$ dan KSS (o,54\%) tertinggi. Tidak ada perbedaan nyata pada rerata nilai kadar abu antara Nglipar dan Panggang dimana kecenderungan ini berlawanan pada nilai KSS. Daerah Panggang mempunyai tempat tumbuh dengan lapisan solum yang tipis dan didominasi batuan tetapi secara statistik tidak berbeda nyata dengan Nglipar untuk parameter kadar abu tetapi di KSS berbeda nyata dengan dua lokasi lainnya. Asumsi yang dipakai adalah dengan lapisan solum yang tipis maka nutrisi dari tanah akan tidak optimal untuk diserap kayu, dalam hal ini terlihat dalam senyawa silikatnya.

Meski tidak semua spesies, umumnya kayu gubal yang masih melakukan proses fisiologi pohon seperti pengangkutan unsur hara mempunyai kadar abu lebih tinggi dibanding terasnya seperti halnya pada kayu Shorea macroptera atau Shorea retusa (Yunanta et al. 2015) dan Robinia pseudoacacia (Adomopoulus et al. 2005). Tetapi hal tersebut tidak terbukti dalam eksperimen kali ini dimana hanya teras dalam saja yang mempunyai nilai terendah secara nyata melalui uji Duncan. Dengan asumsi bagian teras dalam merupakan daerah juvenil, maka diduga kadar abu lebih dpengaruhi oleh efek juvenil dibandingkan
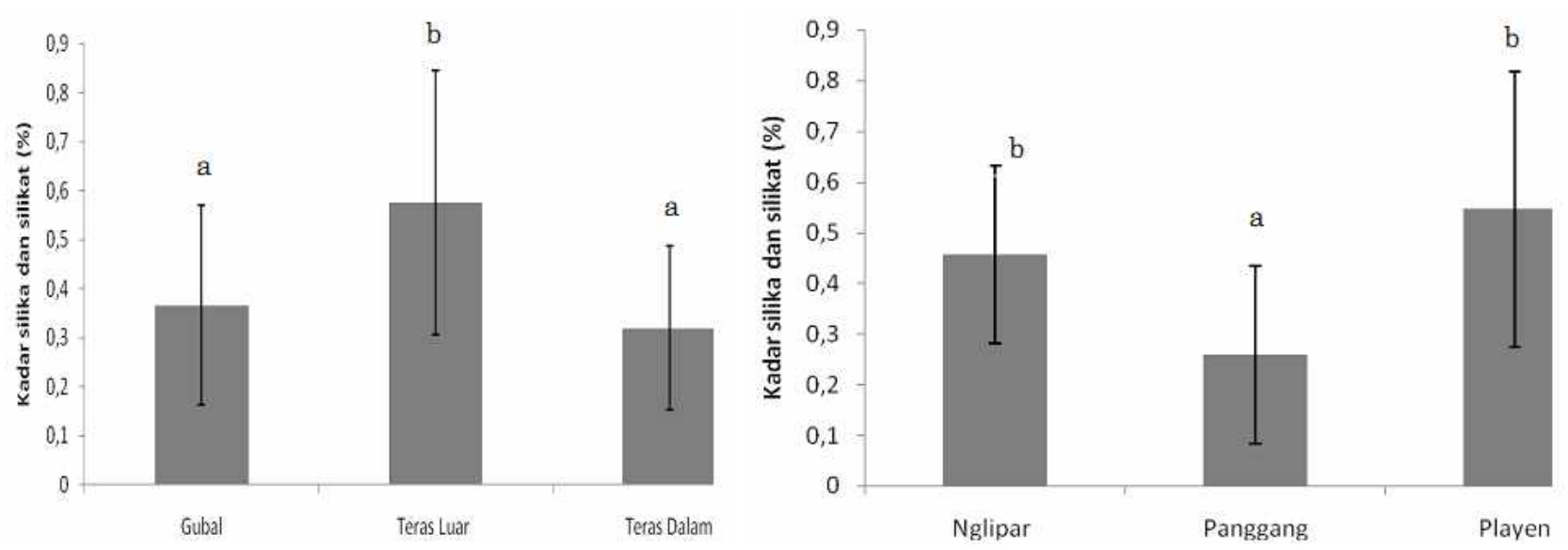

Gambar 1. Kadar silika dan silikat (\% berat serbuk kering tanur) pada kayu jati tumbuh di hutan rakyat Gunungkidul.Huruf yang sama menyatakan tidak berbeda nyata pada $\alpha=5 \%$ pada uji Duncan.

Figure 1. Silica and silicates contents (\% oven-dry meal) of teakwoof of community forests from Gunungkidul Regency. The same letters on the same graphic are not statistically different at $\alpha=5 \%$ by Duncan's test. 
perubahan dari gubal ke teras untuk kayu jati. Meski demikian, untuk KSS menunjukkan beda nyata antara gubal dan teras juga antara teras luar dan teras dalam. Secara matematis, silika dan silikat menyusun sekitar $16 \%-40 \%$ dari total zat anorganik di bagian gubal serta 1\%-63\% di teras dalam penelitian ini. Dengan kisaran jumlah tersebut, silika dan silikat diindikasikan berpengaruh dalam perubahan gubal ke teras maupun dari kayu juvenil ke dewasa.

Kisaran hasil yang didapatkan masih di bawah nilai kadar abu kayu teras luar jati di tegakan Perhutani di KPH Randublatung yaitu o,71\%-3,19\% (Lukmandaru 2011) dan tegakan Perhutani di KPH Purwakarta sekitar 0,97\%-4,10\% (Lukmandaru 2010) tapi masih dalam kisaran jati tumbuh di Brazil yaitu o,7-2,8\% (Polato et al. 2005). Untuk parameter KSS, nilai untuk jati adalah o,4\% (Martawijaya et al. 1981) sedangkan kisaran dari provenans kayu jati bagian teras dari India, Ghana, dan Indonesia yaitu o,22-0,66\% (Kjaer et al. 1998) sehingga menunjukkan lebih tingginya nilai yang diperoleh dari beberapa sampel dari Gunungkidul ini. Secara umum, kayu tropis dicirikan oleh tingginya kadar abu dan silika dibandingkan kayu tumbuh di daerah dingin (Fengel \& Wegener 1989). Tidak diketahui secara pasti penyebab tingginya nilai di hutan rakyat Gunungkidul ini. Tingginya kadar abu maupun silika ini diduga karena pengaruh tidak langsung dari tanaman semusim yang umumnya memerlukan unsur hara dalam jumlah besar dan tumbuh bersama spesies tanaman keras. KSS pada kayu jati yang berasal dari Gunungkidul ini secara teknis tidak menguntungkan untuk proses pengolahan kayu, dimana kayu dengan kandungan silika lebih tinggi dari o,3\% akan menyebabkan alat-alat pemesinan kayu menjadi mudah tumpul (Shmulsky \& Jones 2011).

\section{Kadar unsur-unsur anorganik}

Kisaran pengukuran pada 7 unsur anoganik disajikan pada Tabel 1. Khusus untuk unsur Mn dan $\mathrm{Cu}$, dari batas deteksi minimal yang dipakai, tidak didapatkan adanya elemen tersebut di sampel yang diamati sedangkan unsur Fe hanya terdeteksi di satu sampel saja sehingga ketiga unsur tersebut tidak dianalisis lebih lanjut. Hasil pengujian KolmogorovSmirnov menunjukkan hanya unsur Na saja yang datanya berdistribusi normal. Dari hasil ANOVA (Tabel 2) menunjukkan bahwa hanya faktor radial saja yang berpengaruh nyata dimana dari uji Duncan rerata kadar Na tertinggi (21,72 ppm) secara nyata diamati di bagian teras luar (Gambar 2).

Hasil uji Kruskal-Wallis (Tabel 4) menunjukkan bahwa dari ketiga unsur utama ( $\mathrm{Ca}, \mathrm{K}$, dan $\mathrm{Mg}$ ), faktor radial berpengaruh nyata terhadap kadar $\mathrm{Ca}$ dan $\mathrm{K}$ sedangkan hal sebaliknya terlihat untuk faktor tempat tumbuh. Pengujian Mann-Whitney menunjukkan

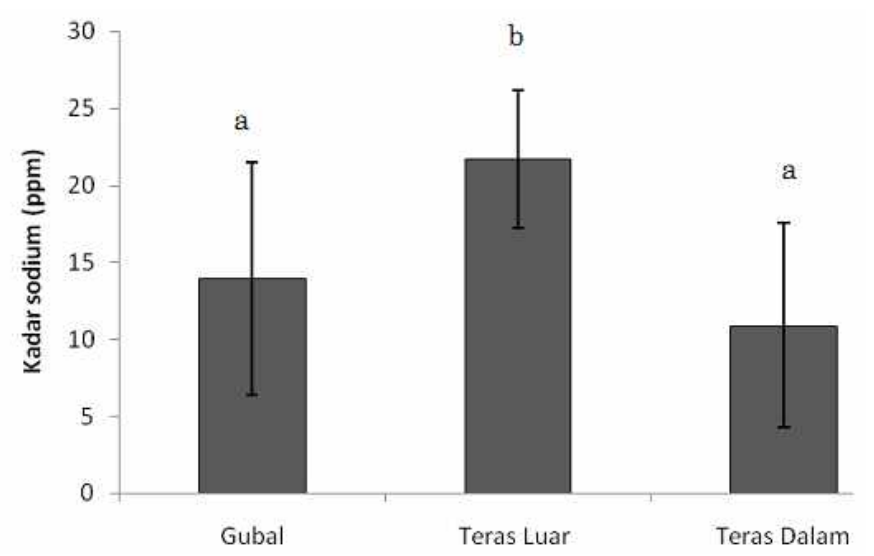

Gambar 2. Kadar sodium (ppm, berat serbuk kering tanur) pada kayu jati tumbuh di hutan rakyat Gunungkidul. Huruf yang sama menyatakan tidak berbeda nyata pada $\alpha=5 \%$ pada uji Duncan.

Figure 2. Sodium content (ppm, oven-dry meal) of teakwoof of teakwood of community forests from Gunungkidul Regency. The same letters on the same graphic are not statistically different at $\alpha=5 \%$ by Duncan's test. 
perbedaan nyata antara gubal dan teras terlihat di kadar Ca dimana rerata kadar Ca tertinggi diperoleh di bagian gubal (1544 ppm). Untuk unsur K, nilai rerata tertinggi (3498 ppm) diamati di bagian teras dalam sedangkan terendah (789 ppm) di teras luar (Gambar 3).

Unsur anorganik utama kayu adalah Ca yang bisa mencapai $50 \%$ dari total zat anorganik diikuti oleh unsur K dan Mg (Fengel \& Wegener 1989). Hasil penelitian dari ketiga tempat tumbuh dan posisi radial menunjukkan unsur anorganik kayu jati yang terdeteksi dalam penelitian ini memiliki kecenderungan kandungan $\mathrm{K}>\mathrm{Mg}>\mathrm{Ca}>\mathrm{Na}$. Penelitian sebelumnya (Lukmandaru et al. 2009) memperoleh kecenderungan $\mathrm{Ca}>\mathrm{K}>\mathrm{Mg}$ di bagian teras normal sedangkan gubalnya adalah $\mathrm{K}>\mathrm{Ca}>\mathrm{Mg}$ di kayu jati yang menunjukkan gejala doreng sebagian. Kecenderungan dalam penelitian ini juga berbeda dengan penelitian Adomopoulus et al. (2005) pada kayu Robinia pseudoacacia dan beberapa kayu daun lebar yang berasal dari Afrika (Ahonkhai 1988), Tsuchiya et al. (2009) pada kayu konifer, dan daun lebar yang berasal dari Jepang dimana kadar tertinggi adalah Ca diikuti K, dan Mg.

Kisaran K dan Mg dari hasil penelitian ini lebih tinggi dibandingkan dengan penelitian pada kayu jati doreng dari Randublatung (Lukmandaru et al. 2009) serta kayu jati yang berasal dari Nigeria (Ola-Adams 1992). Kandungan unsur anorganik Ca dalam penelitian ini lebih rendah dibandingkan provenans kayu jati bagian teras dari India, Ghana, dan Indonesia (Kjaer et al. 1999). Untuk kadar Na tidak dilakukan perbandingan karena tidak ditemukan pustaka kisaran banyaknya $\mathrm{Na}$ di kayu jati. Apabila dibandingkan dengan kayu jenis lain, maka nilai dalam penelitian ini lebih tinggi pada kayu Pinus taeda (McMillin 1970) serta kayu Robinia pseudoacacia (Passialis et al. 2008).

Tabel 4. Uji Kruskal-Wallis dari parameter zat anorganik dari kayu jati hutan rakyat Kabupaten Gunungkidul.

Table 4. Kruskal-Wallis test for inorganic materials parameters of teakwood of community forests from Gunungkidul Regency.

\begin{tabular}{cccccccc}
\hline \multirow{2}{*}{$\begin{array}{l}\text { Sumber } \\
\text { Variasi }\end{array}$} & \multirow{2}{*}{$\mathrm{db}$} & \multicolumn{2}{c}{ Kadar kalsium } & \multicolumn{2}{c}{ Kadar potassium } & \multicolumn{2}{c}{ Kadar magnesium } \\
\cline { 3 - 8 } & & \multicolumn{2}{c}{ Chi-square } & Asym. Sig. & Chi-square & Asym. Sig. & \multicolumn{2}{c}{ Chi-square } & Asym. Sig. \\
\hline $\mathrm{R}$ & 2 & 15,884 & o,o1 $>^{* *}$ & 8,913 & $0,012^{*}$ & 1,750 & 0,417 \\
$\mathrm{~T}$ & 2 & 1,788 & 0,409 & 0,453 & 0,797 & 5,379 & 0,068 \\
\hline
\end{tabular}

Keterangan : T : tempat tumbuh; $\mathrm{R}$ : arah radial; db : derajat bebas; Asym. Sig. : signifikansi asimtot,

$* *=$ beda sangat nyata pada taraf uji $1 \% *$ = beda nyata pada taraf uji $5 \%$

Remarks : $\mathrm{T}$ : sites; $\mathrm{R}$ : radial direction; db : degrees of freedom; Asym. Sig. : asymptotic significance

$* *$ highly significant at $\alpha=1 \%,{ }^{*}=$ significant at $\alpha=5 \%$.
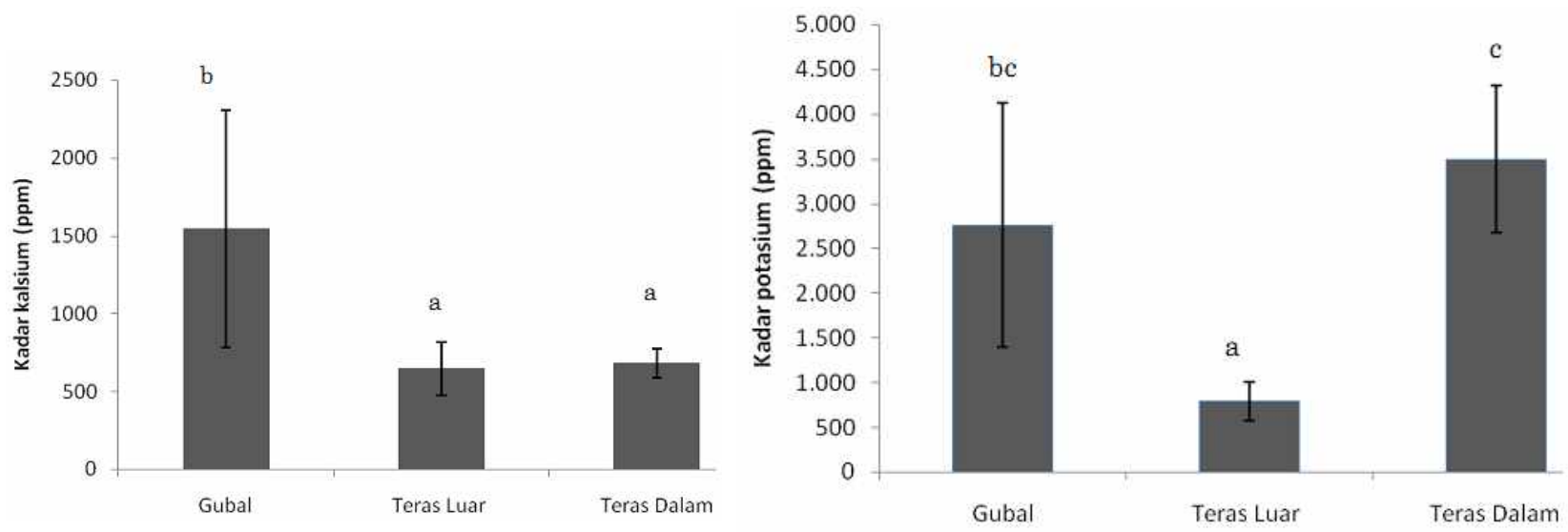

Gambar 3. Kadar kalsium dan potassium (ppm, berat serbuk kering tanur) pada kayu jati tumbuh di hutan rakyat Gunungkidul. Huruf yang sama menyatakan tidak berbeda nyata pada $\alpha=5 \%$ pada uji Mann-Whitney.

Figure 3. Calcium and potassium contents (ppm, oven-dry meal) of teakwood of community forests from Gunungkidul Regency. The same letters on the same graphic are not statistically different at $\alpha=5 \%$ by Mann-Whitney's test. 
Unsur Fe hanya terdeteksi di satu sampel saja yaitu bagian gubal dari satu pohon yang tumbuh di Playen (326 ppm). Sebelumnya, kisaran Fe di kayu jati adalah 30-55 ppm (Lukmandaru et al. 2009). Belum pasti penyebab kecenderungan seperti itu sehingga penelitian lanjutan diperlukan untuk menjelaskan anomali tersebut. Unsur minor seperti $\mathrm{Mn}$ dan $\mathrm{Cu}$ tidak terdeteksi dalam eksperimen ini. Kayu Robinia pseudoacacia yang mengandung unsur anorganik $\mathrm{Mn}$ yaitu 1 - 2 ppm dan Cu 4-5 ppm. Lain halnya pada kayu Pinus taeda dimana kadar unsur anorganik Mn (17,48 - 26,31 ppm) yang relatif besar (Zicherman \& Thomas 1972). Perbedaan unsur-unsur anorganik tersebut kemungkinan disebabkan oleh spesies, genotip, tanah, ekologi, dan iklim (Kozlowski \& Pallardy 1997)

Dari hasil ANOVA kadar unsur-unsur anorganik, interaksi faktor radial dan tempat tumbuh tidak berbeda nyata, sedangkan pada unsur anorganik $\mathrm{Ca}$, $\mathrm{K}$, dan Na dipengaruhi secara nyata oleh arah radial. Okada et al. (1993) melaporkan bahwa kecenderungan unsur anorganik kayu dalam posisi radial ada tiga tipe. Dalam penelitian ini, unsur $\mathrm{Na}$ memiliki kecenderungan bertipe 3 yaitu konsentrasi tertinggi diamati di perbatasan teras-gubal, sedangkan unsur $\mathrm{Ca}$ dan $\mathrm{K}$ kayu jati mempunyai kecenderungan bertipe 1 yaitu meningkatnya konsentrasi dari perbatasan gubalteras menuju arah luar (gubal). Selanjutnya disebutkan bahwa logam golongan alkali umumnya bertipe 1 atau 3. Perubahan nilai yang drastis dari perbatasan gubal ke teras ini diasumsikan bahwa unsur tersebut berperan dalam perubahan gubal ke teras. Antara bagian teras luar dan dalam menunjukkan perbedaan nyata di unsur $\mathrm{K}$ dan Na tetapi dengan kecenderungan yang berlawanan. Hal ini menarik karena kedua unsur tersebut masih dalam satu golongan periodik yang sama yaitu alkali (IA). Diduga kedua komponen tersebut bersifat saling mengganti (substitusi) karena mampu memberikan reaksi kimia yang sama. Di lain pihak, Ca yang termasuk golongan alkali tanah (IIA) menunjukkan tidak ada beda nyata antara teras luar dan dalam.
Penelitian kayu jati doreng untuk satu pohon menunjukkan bagian gubal mempunyai kadar K dan Mg yang lebih tinggi sedangkan kadar Ca lebih rendah dari terasnya (Lukmandaru et al. 2009). Analisis statistik penelitian ini menunjukkan bahwa kandungan Mg tidak memiliki perbedaan nyata pada bagian gubal dan teras. Hal ini juga disebabkan oleh tingginya standar deviasi dalam satu tempat tumbuh. Apabila dibandingkan dengan spesies lainnya, maka kecenderungan tersebut berbeda dengan penelitian Okada et al. (1993) yang secara deskriptif melaporkan bahwa pada beberapa spesies kayu daun lebar dan yang berasal dari Jepang cenderung menunjukkan bahwa unsur-unsur anorganik tersebut kandungannya lebih besar di bagian gubal dibanding terasnya.

Pengaruh tempat tumbuh tidak nyata dalam penelitian ini meski kondisi tanah memberikan nilai yang lebar di parameter Ca total dimana sampel tanah dari Panggang memberikan nilai yang paling tinggi (Tabel 1). Penelitian Kjaer et al. (1999), pada provenans kayu jati dari Indonesia, Ghana, dan Mexico menunjukkan kandungan $\mathrm{Ca}$ dipengaruhi oleh tempat tumbuhnya. Pada spesies lainnya yaitu Robinia pseudoacaia dari Yunani, Bulgaria, dan Hungaria yang secara deskriptif nilai kecenderungan sedikit perbedaan antara tempat tumbuh tersebut (Passialis et al. 2008). Diduga ada faktor lain selain kondisi tanah asal yang berpengaruh terhadap sebaran unsur anorganik seperti iklim atau kondisi lingkungan lainnya (Fengel \& Wegener 1989). Penelitian sebelumnya menyatakan adanya perbedaan curah hujan di ketiga tempat tumbuh tersebut dalam kurun 3 tahun (Marsoem 2013).

\section{Nilai pH}

Nilai pH pada kayu teras berkisar antara 5,53-6,27 dan gubal antara 5,82-6,12. Kisaran hasil dari penelitian ini nilainya sesuai dengan penelitian sebelumnya pada kayu jati dari hutan rakyat Gunungkidul (8 dan 22 tahun) dan Perhutani yaitu 4,8-6,8 (Lukmandaru 2009, 2012). Nilai yang didapatkan juga dalam kisaran jati dari Brazil yaitu 
4,6-6,7 (Polato et al. 2005), namun lebih tinggi dari kayu jati dari Panama yaitu 4,5-5,6 (Windeisen et al. 2003). Dari hasil ANOVA, didapatkan interaksi yang tidak berbeda nyata dan juga pada semua faktornya.

Keasaman kayu dipengaruhi oleh beberapa faktor salah satunya adalah unsur-unsur anorganik (Rowell et al. 2005). Perbedaan nilai $\mathrm{pH}$ maupun unsur anorganik seperti Ca dan $\mathrm{K}$ yang relatif besar di tanah tempat tumbuh yang berbeda (Tabel 1) maupun di kayu tersebut tidaklah otomatis akan memberikan pengaruh yang nyata terhadap nilai $\mathrm{pH}$ di kayunya. Bagian teras secara teoritis lebih asam dibandingkan gubalnya karena ekstraktif fenolat tetapi kecenderungan tersebut tidak diamati dalam penelitian ini. Sebaliknya, perbedaan teras dan gubal terlihat di sampel lain untuk jati dari Gunungkidul dan tegakan Perhutani KPH Randublatung (Lukmandaru 2012) serta dari Panama (Windeisen et al. 2003). Gugus asam bebas dan gugus yang bersifat asam mudah terurai seperti asam asetat dan gugus asetil memengaruhi keasaman kayu (Fengel \& Wegener 1989). Kedua gugus tersebut bisa berasal dari gula nonselulosa maupun ekstraktif fenolat. Penelitian pada sampel yang sama menunjukkan faktor tempat tumbuh dan arah radial berpengaruh nyata terhadap kadar ekstraktif dan hemiselulosa (Lukmandaru et al. 2016). Demikian juga untuk kadar abu dan beberapa unsur anorganik yang dipengaruhi oleh 2 faktor tersebut (Tabel 2 dan 3). Kompleksitas tersebut diduga juga berkontribusi sehingga perbedaan antara gubal dan teras menjadi tidak tegas serta antara tempat tumbuh.

\section{Hubungan antara parameter zat anorganik}

Korelasi antar parameter dari sampel hutan rakyat disajikan pada Tabel 5-7. Fengel dan Wegener (1989) menyatakan kadar abu yang tinggi pada kayu tropis maka kadar silika juga tinggi. Hubungan terkuat diamati diperoleh antara kadar abu dan KSS baik di gubal $\left(r=0,88^{* *}\right)$ dan teras $\left(r=0,84^{* *}\right)$ atau gabungan keduanya $\left(r=0,77^{* *}\right)$. Dari diagram pencar di bagian teras dan gubal (Gambar 4), terlihat bahwa semakin besar kadar abu maka semakin besar pula KSS dengan fungsi kubik (ordo 3). Terlihat adanya 4 titik di bagian teras luar (Nglipar dan Playen) yang menjauhi garis kecenderungan di bagian atas dengan KSS lebih tinggi o,61\%. Sebelumnya, Abosolo et al. (2001) yang melaporkan bahwa kadar abu dengan silika berkorelasi sangat kuat $(r=0,96)$ pada beberapa spesies rotan.

Di luar silika dan silikat, hubungan kadar abu dengan zat anorganik secara nyata diamati pada unsur magnesium $\left(r=0,47^{*}\right)$ di gabungan data gubal dan teras. Di bagian gubal, tidak ada hubungan nyata yang diukur antara kadar abu dan unsur-unsur zat anorganik. Lain halnya di bagian teras, derajat korelasi nyata dihitung antara kadar abu dan kalsium $\left(r=-0,51^{*}\right)$ serta kadar abu dan magnesium $\left(r=0,59^{* *}\right)$. Hubungan keduanya dideskripsikan pada diagram pencar (Gambar 5). Kedua hubungan tersebut sangat berbeda dimana kadar kalsium berkorelasi secara negatif-kuadratik dengan kadar abu sedangkan kadar magnesium berkorelasi secara positif-logaritmis dengan kadar abunya. Selain itu, korelasi nyata kadar abu dan $\mathrm{K}$ juga tidak nyata. Hasil tersebut

Tabel 5. Koefisien korelasi Pearson $(r)$ untuk parameter-parameter zat anorganik pada bagian gubal dan teras kayu jati.

Table 5. Pearson correlation coefficients $(\mathrm{r})$ for the inorganic materials parameters in the sapwood and heartwood regions of teak.

\begin{tabular}{|c|c|c|c|c|c|c|}
\hline & $\begin{array}{c}\text { Kadar silika dan } \\
\text { kadar silikat }\end{array}$ & $\begin{array}{l}\text { Kadar } \\
\text { kalsium }\end{array}$ & $\begin{array}{c}\text { Kadar } \\
\text { magnesium }\end{array}$ & $\begin{array}{c}\text { Kadar } \\
\text { potassium }\end{array}$ & $\begin{array}{l}\text { Kadar } \\
\text { sodium }\end{array}$ & Nilai pH \\
\hline Kadar abu & $0,77^{* *}$ & 0,05 & $0,47^{*}$ & 0,06 & 0,19 & $-0,26$ \\
\hline Kadar silika dan silikat & & $-0,16$ & 0,39 & 0,14 & $0,39^{*}$ & $-0,35$ \\
\hline Kadar kalsium & & & 0,18 & 0,04 & $-0,28$ & $-0,14$ \\
\hline Kadar magnesium & & & & $-0,24$ & 0,20 & 0,04 \\
\hline Kadar potassium & & & & & $-0,24$ & $-0,15$ \\
\hline Kadar sodium & & & & & & $-0,09$ \\
\hline
\end{tabular}


Tabel 6. Koefisien korelasi Pearson $(r)$ untuk parameter-parameter zat anorganik pada bagian gubal kayu jati .

Table 6. Pearson correlation coefficients $(r)$ for the inorganic materials parameters in the sapwood region of teak.

\begin{tabular}{|c|c|c|c|c|c|c|}
\hline & $\begin{array}{c}\text { Kadar silika dan } \\
\text { kadar silikat }\end{array}$ & $\begin{array}{l}\text { Kadar } \\
\text { kalsium }\end{array}$ & $\begin{array}{c}\text { Kadar } \\
\text { magnesium }\end{array}$ & $\begin{array}{c}\text { Kadar } \\
\text { potassium }\end{array}$ & $\begin{array}{l}\text { Kadar } \\
\text { sodium }\end{array}$ & Nilai pH \\
\hline Kadar abu & $0,88^{* *}$ & $-0,13$ & 0,36 & 0,27 & 0,51 & $-0,25$ \\
\hline Kadar silika dan silikat & & 0,01 & 0,47 & 0,18 & 0,44 & $-0,54$ \\
\hline Kadar kalsium & & & 0,50 & $-0,46$ & $-0,45$ & $-0,13$ \\
\hline Kadar magnesium & & & & $-0,38$ & 0,12 & 0,01 \\
\hline Kadar potassium & & & & & 0,11 & 0,21 \\
\hline Kadar sodium & & & & & & $-0,06$ \\
\hline
\end{tabular}

Tabel 7. Koefisien korelasi Pearson $(r)$ untuk parameter-parameter zat anorganik pada bagian teras kayu jati Table 7. Pearson correlation coefficients $(r)$ for the inorganic materials parameters in the heartwood region of teak.

\begin{tabular}{lcccccc}
\hline & $\begin{array}{c}\text { Kadar silika dan } \\
\text { kadar silikat }\end{array}$ & $\begin{array}{c}\text { Kadar } \\
\text { kalsium }\end{array}$ & $\begin{array}{c}\text { Kadar } \\
\text { magnesium }\end{array}$ & $\begin{array}{c}\text { Kadar } \\
\text { potassium }\end{array}$ & $\begin{array}{c}\text { Kadar } \\
\text { sodium }\end{array}$ & Nilai pH \\
\hline Kadar abu & $0,84^{* *}$ & $-0,51^{*}$ & $0,59^{* *}$ & 0,03 & 0,14 & $-0,23$ \\
Kadar silika dan silikat & & $-0,34$ & 0,38 & 0,16 & 0,35 & $-0,32$ \\
Kadar kalsium & & & $-0,46^{*}$ & 0,25 & 0,08 & 0,15 \\
Kadar magnesium & & & $-0,29$ & 0,26 & 0,07 \\
Kadar potassium & & & & & 0,19 & $-0,24$ \\
Kadar sodium & & & & & $-0,16$ \\
\hline
\end{tabular}

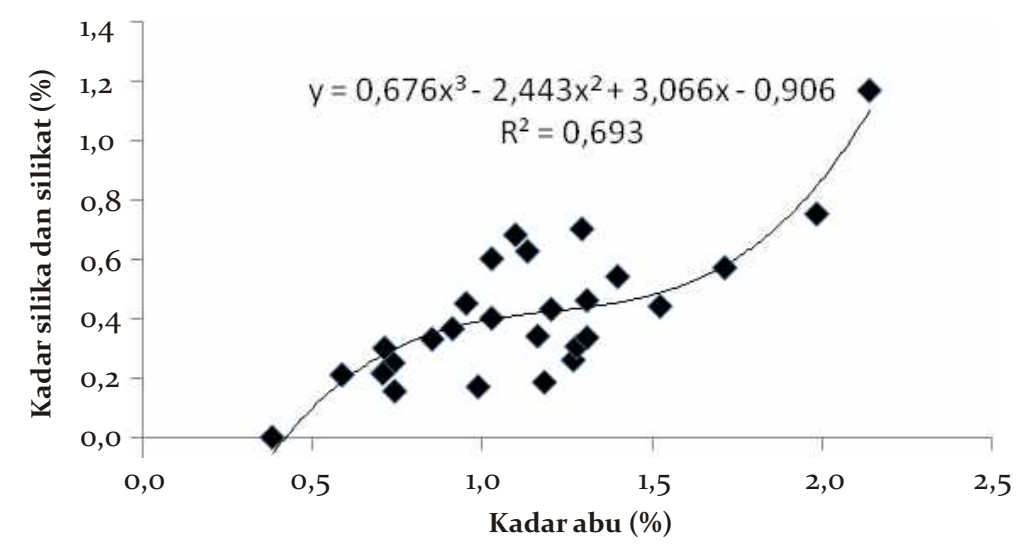

Gambar 4. Diagram pencar antara kadar abu dan silika-silikat di kayu teras dan gubal jati

Figure 4. Scatterplots between ash content and silica-silicates in the heartwood and sapwood of teak

mengindikasikan meski $\mathrm{Ca}, \mathrm{Mg}$, dan $\mathrm{K}$ merupakan komponen utama zat anorganik penyusun kayu tetapi menunjukkan kecenderungan yang bervariasi terhadap kadar abunya. Di spesies lainnya, Kubo dan Ataka (1998) melaporkan pada kayu Cryptomeria japonica pada bagian teras yang menghitam terdapat korelasi antara kadar abu dan kadar $\mathrm{K}(r=0,67)$

Dalam hubungan antara unsur-unsur anorganik didapatkan dua korelasi nyata yaitu antara KSS dan $\mathrm{Na}\left(r=0,39^{*}\right)$ di gabungan gubal dan teras serta antara kadar Ca dan $\mathrm{Mg}\left(r=-0,46^{*}\right)$ di bagian teras. Hubungan tersebut mengindikasikan bahwa semakin tinggi KSS akan diikuti kadar $\mathrm{Na}$, sedangkan kenaikan kadar $\mathrm{Ca}$ akan diikuti oleh penurunan kadar Mg (Gambar 6). Secara teoritis dalam tabel periodik unsur, $\mathrm{Na}$ dan $\mathrm{Si}$ tergolong dalam unsur yang berbeda yaitu alkali (IA) dan logam peralihan (metaloid). Adanya hubungan ini diduga unsur Na dan Si saling melengkapi dalam proses fisiologi pohon meski sifat kimianya berbeda. Fungsi silika dalam fisiologi pohon yang salah satunya adalah melindungi tanaman terhadap serangan organisme lain serta cuaca yang kurang baik (Abasolo et al. 2001) sedangkan $\mathrm{Na}$ berfungsi meningkatkan 
pertumbuhan tanaman meski tidak dianggap komponen esensial (Kozlowski \& Pallardy 1997).

Ca dan $\mathrm{Mg}$ termasuk dalam golongan periodik yang sama yaitu IIA atau alkali tanah. Kesamaan tersebut diharapkan akan memberikan reaksi yang sama pada kedua unsur tersebut (valensi $2^{+}$). Meski demikian, Ca merupakan unsur immobile karena berperan dalam mekanik dinding sel sedangkan $\mathrm{Mg}$ merupakan unsur mobile dan katalis dalam reaksireaksi enzimatis dalam proses fisiologi pohon (Okada et al. 1987) sehingga hal tersebut diduga bisa menyebabkan perbedaan kecenderungan terhadap kadar abunya. Tidak ada korelasi nyata antara kadar abu dan zat anorganik tunggal di bagian gubal diinterpretasikan sebagai masih aktifnya proses fisiologi sehingga unsur anorganik cukup mobile dalam penyebarannya, sedangkan di teras relatif tidak mobile karena sel-sel di teras sudah mati.

Korelasi antara nilai $\mathrm{pH}$ dengan kadar zat-zat anorganik pada sampel hutan rakyat tidak menunjukkan adanya derajat korelasi yang nyata. Secara teoritis, Ca beserta unsur utama anorganik kayu seperti Mg dan K lebih bersifat basa. Okada et al. (1987) berasumsi tingginya kandungan logam tersebut sebagai counter ion untuk zat polifenolat yang terbentuk pada bagian teras. Hasil ini juga menguatkan pengaruh yang tidak nyata dari faktor arah radial dan tempat tumbuh terhadap nilai $\mathrm{pH}$ (Tabel 2). Ke depannya perlu penelitian lanjutan untuk menjelaskan sejauh mana parameter-parameter sifat kimia seperti zat anorganik, kadar ekstraktif, dan gugus asetil gula berpengaruh pada $\mathrm{pH}$ di kayu jati.

\section{Kesimpulan}

Dari pengukuran sampel kayu jati dari hutan rakyat Gunungkidul di 3 tempat tumbuh dan arah radial pohon yang berbeda diperoleh data yaitu kadar abu adalah $0,38-2,62 \%$ serta kadar silika dan silikat o,o1-1,17\%. Meskipun relatif tinggi, tetapi nilai tersebut umum dalam spesies kayu tropis. Kisaran nilai kadar zat anorganik adalah Ca 408-2919 ppm; K 69-23705 ppm, Mg 947-1653 ppm, Na 4-31 ppm, dan Fe adalah 0-326 ppm. Mn dan $\mathrm{Cu}$ tidak terdeteksi di semua sampel. Kisaran nilai $\mathrm{pH}$ yang diperoleh masih dalam kisaran asam lemah $(5,23-6,98)$. Faktor tempat tumbuh berpengaruh nyata terhadap kadar abu dan silika-silikat, sedangkan arah radial berpengaruh nyata terhadap kadar abu, silika-silikat, $\mathrm{Ca}, \mathrm{Na}$, dan $\mathrm{K}$. Nilai kadar abu dan silika-silikat di sampel kayu Gunungkidul ini relatif tinggi, meskipun keawetan alami menjadi lebih tinggi tetapi dalam pengolahan kayunya kurang menguntungkan karena dikhawatirkan kayunya semakin keras dan mudah menumpulkan alat pemotong atau gergaji. Tidak ada pengaruh nyata kedua faktor di atas terhadap nilai $\mathrm{pH}$. Dari analisis korelasi Pearson, hubungan kuat diamati antara kadar abu dengan kadar silika-silikat ( $r=$

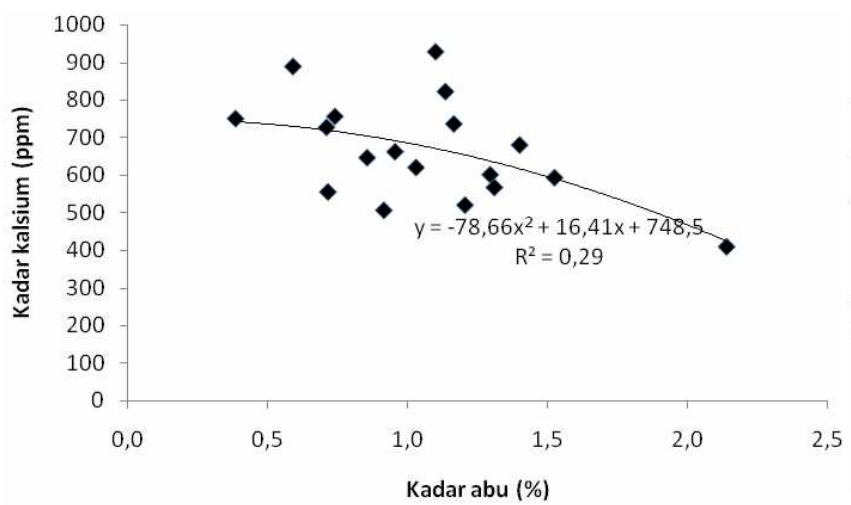

(a)

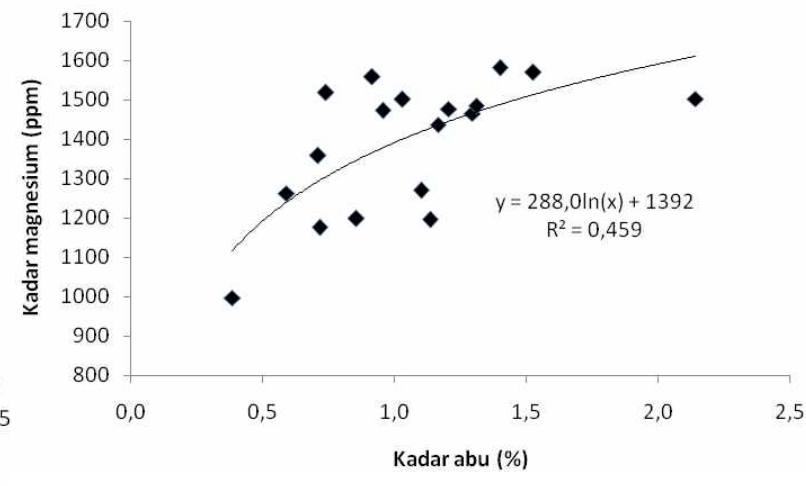

(b)

Gambar 5. Hubungan negatif antara kadar abu dan kalsium (a) serta hubungan positif antara kadar abu dan magnesium (b) Figure 5. Negative relationship between ash and calcium contents (a) and positive relationship between ash and magnesiun contents (b) 


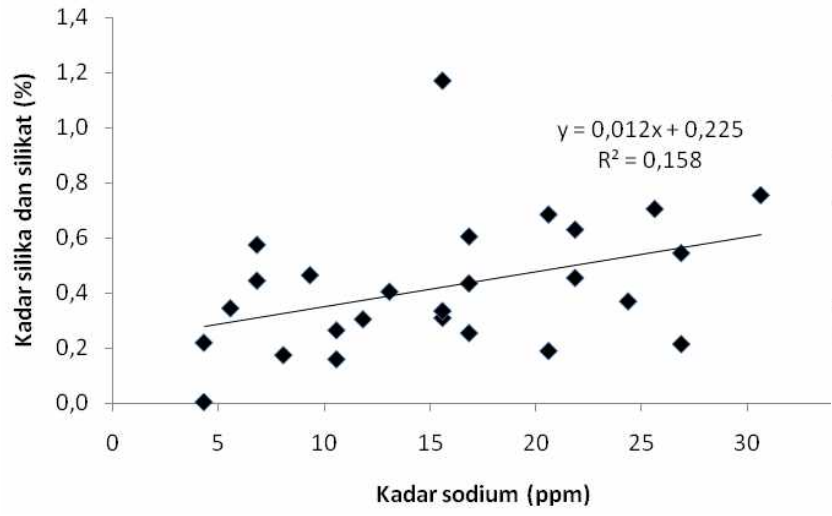

(a)

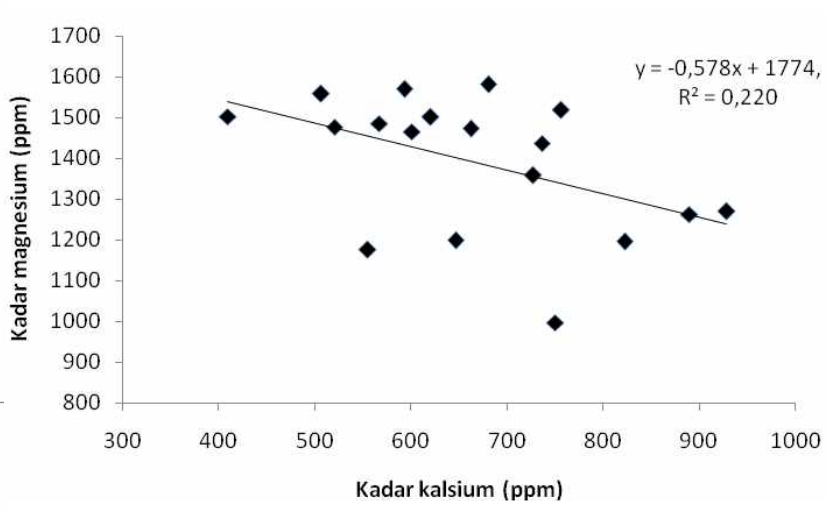

(b)

Gambar 6. Hubungan positif antara kadar silika dan silikat dengan sodium (a) serta hubungan negatif antara kadar magnesium dan kalsum (b) di bagian teras.

Figure 6. Positive relationship between silica-silicates and sodium contents (a) and negative relationship between magnesium and calcium contents (b) in the heartwood.

0,77-0,88) serta kadar abu-Ca $(r=-0,51)$ dan kadar abu-Mg $(r=0,59)$ di bagian teras. Dalam tingkat unsur, hubungan terkuat diamati pada kadar Ca-Mg ( $\mathrm{r}=$ -o,46). Tidak ada korelasi nyata antara nilai $\mathrm{pH}$ dan parameter- parameter zat anorganik.

\section{Ucapan Terima Kasih}

Penelitian ini sebagian dibiayai oleh Hibah DPP Fakultas Kehutanan UGM 2013. Penulis mengucapkan terima kasih kepada Daryono Prehaten (Departemen Silvikultur, Fakultas Kehutanan UGM) yang membantu dalam analisis kimia tanah.

\section{Daftar Pustaka}

Abasolo WP, Yoshida M, Yamamoto H, Okuyama T. 2001. Silica in several rattan species. Holzforschung 55:595-600

Adamopoulus S, Voulgaridis E, Passialis C. 2005. Variation of certain chemical propeties within the stemwood of Black Locust (Robina pseudoacacia L). Holz als Roh- und Werkstoff 63: 327-333.

ASTM International. 2002. D-1102 Test methods for ash in wood. Annual Book of ASTM Standards 2002, Section 4: Construction. Hlm. 175. West Conshohocken, PA .

Dewan Standardisasi Nasional. 1989. SNI 14-1031-1989. Cara uji kadar abu, silika dan silikat dalam kayu dan pulp kayu.

Fengel D, Wegener G. 1995. Kayu: Kimia, ultrastruktur, reaksi-reaksi. Prawirohatmojo S, editor. Sastrohamidjojo H, penerjemah. Gadjah Mada University Press, Jogjakarta

Hachmi A, Moslemi AA. 1990. Effect of wood pH and buffering capacity on wood-cement compatibility. Holzforschung 44:425-430.
Kanazawa H, Nakagami T, Nobashi K, Yokota T. 1978. Studies on the gluing of the wood. Articles XI. The effects of teak wood extractives on the curing reaction and the hydrolysis rate of the urea resin. Mokuzai Gakkaishi 24:55-59.

Kjaer ED, Kajornsrichon S, Lauridsen SB. 1998. Heartwood, calcium and silika content in five provenances of teak (Tectona grandis L). Silvae Genetica 48:1-3.

Kozlowski TT, Pallardy SG. 1997. Physiology of woody plants. Academic Press Inc., California

Kubo T, Ataka S. 1998. Blackening of sugi (Cryptomeria japonica D Don) heartwood in relation to metal content and moisture content. Journal of Wood Science 44:137-141.

Kuhn AJ, Schröder WH, Bauch J. 1997. On the distribution and transport of mineral elements in xylem, cambium, and phloem of spruce (Picea abies[L] Karst). Holzforschung 51:487-496.

Lukmandaru G. 2010. Sifat kimia kayu jati (Tectona grandis) pada laju pertumbuhan berbeda. Jurnal Ilmu dan Teknologi Kayu Tropis 8(2):188-196.

Lukmandaru G. 2011. Komponen kimia kayu jati dengan pertumbuhan eksentris. Jurnal Ilmu Kehutanan 5(1):21-29

Lukmandaru G. 2012. Sifat kelarutan dalam air, keasaman dan kapasitas penyangga pada kayu jati. Hlm. 875-882 dalam Sulistyo J, Widyorini R, Lukmandaru G, Rofii MN, Prasetyo VE, editor. Prosiding Seminar Nasional XIV MAPEKI. Yogyakarta.

Lukmandaru G. 2013. The natural termite resistance of teak wood grown in community forest. Jurnal Ilmu dan Teknologi Kayu Tropis 11(2):131-139.

Lukmandaru G. \& Sayudha IGN. 2012. Komposisi ekstraktif pada kayu jati juvenil. Hlm. 361-366 dalam Sulistyo J, Widyorini R, Lukmandaru G, Rofii MN, Prasetyo VE, editor. Prosiding Seminar Nasional XIV MAPEKI. Yogyakarta.

Lukmandaru G, Ashitani T, Takahashi K. 2009. Color and chemical characterization of partially black-streaked heartwood in teak (Tectona grandis L.f). Journal of Forestry Research 20:377-380. 
Lukmandaru G, Mohammad AR, Wargono P. 2016. Studi mutu kayu jati di hutan rakyat Gunungkidul. V. Sifat kimia kayu. Jurnal Ilmu Kehutanan 1o(2):108-118.

Marsoem SN. 2013. Studi mutu kayu jati di hutan rakyat Gunungkidul. I. Pengukuran laju pertumbuhan. Jurnal Ilmu Kehutanan 7(2):108-122.

Marsoem SN, Prasetyo VE, Sulistyo J, Sudaryono, Lukmandaru G. 2014. Studi mutu kayu jati di hutan rakyat Gunungkidul. III. Sifat fisika kayu. Jurnal Ilmu Kehutanan 8(2):76-89.

Marsoem SN, Prasetyo VE, Sulistyo J, Sudaryono, Lukmandaru G. 2015. Studi mutu kayu jati di hutan rakyat Gunungkidul. IV. Sifat mekanika kayu. Jurnal Ilmu Kehutanan 9(2):117-127.

Martawijaya A, Kartasudjana I, Kadir K, Amongprawira S. 1981. Atlas Kayu Indonesia Jilid I. Hlm. 42-47. Balai Penelitian Hasil Hutan. Badan Litbang Kehutanan. Bogor.

Mayer I, Koch G. 2007. Element content and $\mathrm{pH}$ value in American black cherry (Prunus serotina) with regard to colour changes during heartwood formation and hot water treatment. Wood Science and Technology 41:537-547.

McMillin WC. 1970. Mineral content of loblolly pine wood as related to specific gravity, growth rate, and distance from pith. Holzforschung 15:1-5.

Minato K, Morita T. 2005. Blackening of Diospyros genus xylem in connection with boron content. Journal of Wood Science 51:659-662.

Okuda N, Katayama Y, Nobuchi T, Ishimaru Y, Yamashita H, Aoki A. 1987. Trace elements in the stems of trees I. Radial distribution in sugi (Cryptomeria japonica D. Don). Mokuzai Gakkaishi 33:913- 920.

Okuda N, Katayama Y, Nobuchi T, Ishimaru Y, Yamashita H, Aoki A. 1993. Trace elements in the stems of trees VI. Comparisons of radial distributions among hardwood stems. Mokuzai Gakkaishi 39: 1119- 1127.

Ola-Adams AB. 1992. Effects of spacing on biomass distribution and nutrient content of Tectona grandis Linn. f. (teak) and Terminalia superba Engl. \& Diels. (afara) in South-Western Nigeria. Forest Ecology and Management 58:299-319.

Passialis CE, Voulgaridis S, Adamopoulos S, Matsouka M. 2008. Extractives, acidity, buffering capacity, ash and inorganic elements of black locust wood and bark of different clones and origin. Holz als Roh- und Werkstoff 66: 395-400.

Polato R, Laming PB, Sierra-Alvarez R. 2003. Assessment some wood characteristics of teak of Brazilian origin. Hlm 257-265 dalam Bhat KM, Nair KKN, Bhat KV, Muralidharan EM, Sharma JK, editor. Proceeding of the International Conference on Quality Timber Products of Teak from Sustainable Forest Management. Kerala, India.

Rowell R, Pettersen R, Han JS, Rowell JS, Tshabalala MS. 2005. Cell wall chemistry. Hlm. 50 dalam Rowell R, editor. Handbook of wood chemistry and wood composites. CRC Press. Boca Raton-London-New York-Washington D.C.

Shmulsky R, Jones PD. 2011. Forest products and wood science: An introduction, Sixth edition. Hlm. 45. John Wiley \& Sons, Inc. West Sussex, UK.
Takahashi K. 1996. Relationships between the blacking phenomenon and norlignans of sugi (Cryptomeria japonica D Don) heartwood I. A case of partially black heartwood. Mokuzai Gakkaishi 42:998-1005.

Tsuchiya Y, Shimogaki H, Abe H, Kagawa A. 2010. Inorganic elements in typical Japanese trees for woody biomass fuel. Journal of Wood Science 56:53-63.

Windeisen E, Klassen A, Wegener G. 2003. On the chemical characterization of plantation teakwood (Tectona grandis L) from Panama. Holz als Roh- und Werkstoff 61:416-418.

Xing C, Zhang SY, Deng J. 2004. Effect of wood acidity and catalyst on UF resin gel time. Holzforschung 58:408-412.

Yunanta RRK, Lukmandaru G, Fernandes A. 2014. Sifat kimia dari kayu Shorea retusa, Shorea macroptera, dan Shorea macrophylla. Jurnal Penelitian Dipterokarpa 8:15-25.

Zicherman BJ, Thomas RJ. 1972. Analysis of loblolly pine ash materials. Holzforschung 4:1-4 